\title{
The Lesiri Concept: An Indigenous Mechanism for Solving Chieftaincy Conflicts among Waala of the Upper West Region of Ghana
}

\author{
Hafiz Bin Salih \\ Wa Municipal Education Office, Ghana Education Service, Wa, Ghana \\ Email: hafizbinsalih@yahoo.com
}

How to cite this paper: Salih, H.B. (2018) The Lesiri Concept: An Indigenous Mechanism for Solving Chieftaincy Conflicts among Waala of the Upper West Region of Ghana. Open Journal of Social Sciences, 6, 147-170.

https://doi.org/10.4236/jss.2018.68012

Received: July 27, 2018

Accepted: August 20, 2018

Published: August 23, 2018

Copyright $\odot 2018$ by author and Scientific Research Publishing Inc. This work is licensed under the Creative Commons Attribution International License (CC BY 4.0).

http://creativecommons.org/licenses/by/4.0/

\begin{abstract}
The purpose of the research paper was to discover and describe indigenous mechanisms of resolving chieftaincy conflict among the Waala of the Upper West Region of Ghana. The Lesiri concept is an indigenous mechanism for solving chieftaincy conflicts among Waala of the Upper West Region of Ghana. The research paper endeavoured to address several essential questions which assisted the researcher in documenting the findings of the study. The researcher undertook a review of literature in the area of the nature of chieftaincy dispute and conflict resolution. Both qualitative and quantitative approaches were used. There are provisions within Waala society and in the Kingdom for indigenous means of dispute resolution that have been relegated to the background. It was discovered in the study that these indigenous approaches have the potency to resolve chieftaincy conflicts among the Waala royals. The study discovered that the use of the formal law courts have not been effective in resolving the persistent Wa chieftaincy conflict. It was also discovered that a disregard for indigenous conflict resolution approach has been a contributory factor to the inability of feuding parties to find a solution to the persistent Wa chieftaincy conflict. This research paper is an aspect of my unpublished $\mathrm{PhD}$ thesis.
\end{abstract}

\section{Keywords}

Chieftaincy, Conflict, Conflict Resolution, Lesiri

\section{Introduction}

In the Waala political system, conflict is considered as something to be expected [1]. The Wa chieftaincy conflict was also cited as the primary reason for the insecurity of the Wa Municipality by $70 \%$ of participants in a study carried out by 
the [2] and the United Nations Human Security Programme. Thus, the Wa chieftaincy conflict is both common and widespread. Consequently, Waala Royals compete at every turn, at times behaving in unnecessarily bitter and spiteful ways that threatens societal peace and order. The continuous side-stepping of the Naa Kpaaha gate whenever there is a vacancy is one primary factor for the Wa chieftaincy conflict. The Waala kingdom has experienced numerous incidents of violence as a result of the competing claims and rivalry which have had a severe impact on development. Furthermore, those living in poverty in the Wa municipality now faces even greater poverty since investors are turning their back on the area to avoid personal losses, harm or even death. Similarly, these conflicts have had a restrictive impact on business activities and sometimes resulting in needless deaths and the destruction of lives [3].

The royal gates of the Jarri, Joyonhi, Kpaaha and Yijiihi are often granted the Wa skin as a hereditary right [1]. Until the British Colonial Administration introduced the rotational accession to the skin in the Waala constitution of 1933, the norm was that the most senior prince among the Waala Royals was most often enskinned the chief. It is for this reason that [4] states that "the Waala chiefdom was a gerontocracy". However, the four gates are now in a state of constant conflict over the rights to the skin, particularly given the status of the Wa Naa and also as a result of the sustained efforts of the other three royal gates to deny the Naa Kpaaha gate the opportunity also to occupy the Wa skin. Consequently, Naa Kpaaha princes act with blinkered determinism to secure what they believe is their rightful place. Under the 1933 Waala constitution, only the Waala princes (Nabiihi) have the birthright to the Wa skin. According to [5], only the Jonyohi, Jarri and Yijiihi are given the right to the Waala skin under the decree of the Waala elders and Wa Naa Pelpuo III, established in 1933 in response to the British Colonial Administration's attempts to codify the Waala customs and traditions. Over the decades that have followed the signing of the 1933 Waala constitution, the right to the Waala skin (especially about the Kpaaha royal gate versus the other three gates) has become the primary reason behind the Waala kingdom's chieftaincy conflict. In the same vein, [6] asserts that the 1933 Waala constitution's failure to highlight Naa Kpaaha gate's right to the skin is the fundamental problem leading to chieftaincy conflict in the Wa kingdom today.

Indeed, only the Jarri, Joyonhi, and Yijiihi gates were identified as having the rights to the skin under the Waala constitution of 1933 [7]. Therefore, the Waala royal family has suffered from a wave of conflict over the legitimacy of the unlisted Naa Kpaaha gate, with candidates from each gate fighting for their place despite the rotation and gate systems put in place. The other three royal gates are of the opinion that, descendants of the Naa Kpaaha gate are not true-blue Royals of the Waala royal family. They contend that Naa Kpaaha succeeded his brother Naa Pelpuo, but he did not have a child of his own though he was married to many women. Upon ascending the throne, he married a young lady who begot a male child. The child was never accepted as a son of Naa Kpaaha. Hence, the descendants of this child have never been accepted as legitimate Royals of the 
Wa skin. That has been the plight of the Naa Kpaaha gate [4]. Believing that their right to the skin is legitimate, the Naa Kpaaha gate fought against the 1933 Waala constitution for over 50 years and insisted that the other gates acknowledge its right to the skin. The Naa Kpaaha's protests were heard by Ghana's Supreme Court, which granted the gate the right to the skin on 29th August, 1985. However, Yakubu Seidu Soali II, the then-head of the Naa Kpaaha royal gate, could not immediately become the Wa Naa. Instead, he was on standby to become the next chief after the death of Wa Naa Momori. Because Wa Naa Momori's reign was surrounded by controversy, Yakubu Seidu Soali II's right to become Wa Naa was not automatic even after the passing away of Wa Naa Momori. The dispute between the Naa Kpaaha gate and the other three gates continued.

According to [5], the Joyonhi and Kpaaha royal gates' conflict over the rights to the Wa skin reached a crescendo in 1979, becoming one of the worst and most prolonged examples of chieftaincy conflicts ever seen. The conflict commenced following the passing away of Wa Naa Sidiki Bomi II earlier that year. In line with Waala tradition, the death was reported to the Tendaana by the head of the princes. The Tendaana, his associates and the Muslim Yari-Namine were summoned to a meeting. As per tradition, the head of the princes then declares the execution of the Wa Naa's burial rites. Following this, the successor to the Wa skin is determined by consensus.

The rotation system as mentioned earlier plays a major role in the determination of a successor, as per Waala tradition. In the case of Wa Naa Sidiki Bomi II's death, the Tendaana supported the enskinment of the Naa Kpaaha gate's candidate, Yakubu Seidu. Busa Naa Asan Dzie was the main opponent to this suggestion. He proposed that the Divisional Chief of Sing, Iddi Bukpali, would be better suited for the role. Bukpali himself nominated the Sing sub-chief, Chansa Naa, J. N. Momori.

While Naa Momori was regarded as Wa Naa, his time in leadership was plagued by constant legal conflict and unrest. Furthermore, his nomination and succession were avidly opposed by Yakubu Seidu, leading to a prolonged hearing at the Bolgatanga-based Upper Regional House of Chiefs' Judicial Committee. Eventually, the Kumasi-based National House of Chiefs' Judicial Committee took over the case. Here, it was determined that the Naa Kpaaha gate shared the same rights to the Wa skin as the other three gates. On 29th August, 1985, Ghana's Supreme Court took a decision regarding the legitimacy of the fourth gate's rights to the Wa skin [8].

Some issues came to light as a result of this prolonged legal inquiry. One of these was Momori's argument that the six rightful kingmakers had all chosen him. The claim was disputed by those who argued that there were, in fact, seven kingmakers. As a result of the ruling of the Supreme Court, Momori's position as the Wa Naa was backed with the official support of the kingmakers at a meeting held in Wa. However, Naa Yakubu Seidu declined the invitation to attend the kingmakers' meeting [8]. 
A kingmakers' meeting, called to appoint a new Wa Naa, was held on 20th April, 1998 following the death of Wa Naa Momori Bondiri II on 16th January, 1998. The execution of the burial rites followed later. A legal dispute once again commenced. Waala kinship trust and respect for chieftaincy began to decline. At this time, the Naa Kpaaha gate was still recovering from the enskinement of the Joyonhi gate's Momori Bondiri's enskinment as Wa skin following Wa Naa Seidu's death in 1979. The Kpaaha gate was of the conviction that they would have occupied the skin of the Wa Naa after the demise of Wa Naa Seidu, but this was not to be. In this round, the rivals were the Kpaaha gate's Gulli Naa, Naa Yakubu Seidu and the Yijiihi gate's Katua Naa, Naa Hamidu Yakubu. Because both parties argued that they had each won the election (i.e. from the seven kingmakers), no decision could be made on the appointment of the Wa Naa [8]. This was strange because the voting was done in the open by Waala tradition but the issue could not be resolved due to the tensed atmosphere and the delicate nature of the voting. As a result, the Upper West Regional House of Chiefs' Judicial Committee began yet another drawn-out legal proceeding. While the other three gates were displeased with the ruling, the Judiciary Committee granted the Kpaaha gate the rights to the skin. This led to further discord in Wa. Peace was maintained by police and military forces for a time, but two civilians were shot and hospitalised on 29th August, 2000 due to a resurgence of conflict [8].

[8], reports that although the legitimacy of Wa Naa Alhaji Yakubu Seidu Soale II was approved, a number of the royal factions strongly opposed the validity of the decision. Alhaji Issa Seidu of the Yijiihi Funsi Naa subsection, who gained support from the Kpamaata (i.e. the "three Spears" of Yijiihi, Jarri and Jonyohi), also asserted his right of nomination as Wa Naa. Consequently, while not officially enskinned, Alhaji Issa Seidu was given the title of Kpamaata Naa ("chief of the three Spears") and roughed shoulders with the Wa Naa.

At this time, the town of Wa faced security threats and conflict once more. [9] reports that this led to the deployment of government-assigned security forces in an attempt to keep the peace following Alhaji Yakubu Seidu's appointment as the chief of the Waala Traditional Area and protests by the other three gates. The Upper West Regional Security Council (REGSEC) raised the issue. Ayim (1999) further adds that despite the opposition of the Jarri, Joyonhi, and Yijiihi gates, the National House of Chiefs supported the Judicial Committee of the Upper West Regional House of Chief's decision to appoint Naa Yakubu Seidu as the Wa Naa. Consequently, the three gates attempted to appeal against this decision with the Supreme Court. However, the National House of Chiefs did not approve the right of appeal. On the 11th of March, 2002, Naa Seidu was officially granted the title and role of Wa Naa. Soon after this event, Naa Seidu declared his plan to become initiated on 8th April that year via a letter addressed to the Upper West Regional Coordinating Council (RCC). In response to this letter, the RCC advised Naa Seidu to wait until confirmation was given regarding the security of the region. Wa Naa Soale II continued to serve as Wa Naa until the 
3rd of September, 2006, when he passed away at the age of 78 years at his royal palace.

As reported by [10], Wa Naa Soale II's passing on provided an opening for candidates interested in becoming the next Wa Naa. Consequently, three candidates-all of whom belonged to the Yijiihi gate-presented themselves for the title. One of these candidates was self-appointed Wa Naa Seidu Issah. This was a strange and interesting move given his earlier position. Indeed, Awedoba [6] comments that during Naa Soalia II's time in power, Seidu Issah had bestowed upon himself the title of the Wa Naa-a title he still asserts to possess up to date.

The three candidates vying to become $\mathrm{Wa} \mathrm{Naa}$ during this period were Issa Seidu (Funsi Naa-Jaga), Yakubu Asani (Dinorkpong) and Fuseini Seidu (PelpuoJaga). Thus, only the Naa Soboung subsection of the Yijiihi gate had no representation for the Wa skin. Issa Seidu presented himself as the rightful successor, supported by the Jarri, Joyonhi and Yijiihi gates. He insisted that his outdooring should take place on the 27th of January, 2007. In spite of this move, Fuseini Seidu was nominated successor of the Wa Naa on the 19th of January, 2007 by the Wa kingmakers [10]. Naturally, Fuseini's election failed to receive approval from the representatives of the other three Yijiihi subsections. Nonetheless, Fuseini was enskinned on the 21st of January, 2007 and out-doored the following day. He adopted the skin name Wa Naa Fuseini Tangile Pelpuo IV.

The other three subsections were not alone in opposing the decision. According to the Ghanaian Times [11], Gbetore Naa Alhaji Issa Bukari clearly stated his refusal to support the election of Fuseini Seidu of Pelpuo-Jaga and also voiced the opposition of the three other gates at a press conference held at the time. According to Gbetore Naa Alhaji Issa Bukari, there was no validity in the decision. He emphasised the disapproval of the elders of the Jarri, Joyonhi and Yijiihi gates and chiefs because the election process failed to adhere to traditional Waala procedures. He added that the Wa Tendaana had no jurisdiction to call an election meeting under the traditional Waala custom. Instead, he argued that only the Wa skin's head of princes had the authority call for such proceedings.

The dispute over Wa Naa Fuseini Pelpuo's enskinment reached its peak with the shooting and killing of an individual during an attempted assassination of the Wa Naa, as reported in the [12]. The shooting occurred not long after Wa Naa Fuseini, the rightful Wa Naa, in accordance with the 5th of May, 2012 ruling of/by the National House of Chiefs, was given the keys to the royal palace by the Upper West Regional Coordinating Council. According to the Daily Graphic's article, immediate efforts were made by police and military forces to curtail further conflict in the region following the attempted assassination.

Communities within Wa have been greatly affected by chieftaincy conflicts and their aftermath. In fact, a great deal of resources was spent by the $\mathrm{Wa} \mathrm{Mu}$ nicipal Assembly on peace-keeping efforts between 2002 and 2008. According to [13], these investments could have been made in the areas of development and quality-of-life projects instead of being wasted on fixing unnecessary chieftaincy 
conflicts. Furthermore, [14] reminds us that besides/apart from economic and developmental issues, conflict negatively affects all aspects of civilian life by compromising community sense of hope, access to wealth, harmony, joy and quality of life. Another significant issue is the risk of further conflict and destruction arising from the growing prevalence of guns in the Wa Municipality.

The government must remain uninvolved with chieftaincy conflict and resist interfering with problems that should be dealt with within the chieftaincy institution.

Some dissatisfaction has been noted with the modern legal system as the system has become more complicated over the years. This report warrants an assessment with the quest to unearth possible causes for the failure of the modern court in chieftaincy dispute settlement. The respondents to the questionnaire survey all agreed that the modern court structures have not been successful at handling chieftaincy conflicts. This is the case even though the contribution of the chiefs was all but eliminated and replaced by the formal court system.

\section{Statement of the Problem}

This research paper is to discover and describe indigenous mechanisms of resolving chieftaincy conflict among the Waala of the Upper West Region of Ghana.

\section{Research Method}

The mixed method approach was used for the research. The combination of qualitative and quantitative approaches in data collection and analysis is accepted in the social sciences.

\subsection{Identification and Selection of Study Sites, Study Population and Sample Size}

The research explored the experiences of some people residing within the four divisional gates of the Waala paramountcy: Busa, Guli, Kperisi and Sing. The target sample for this study were chiefs, local opinion leaders and, officials of the Regional House of Chiefs, the Waala Traditional Council, the Wa Municipal Assembly and the Wa Municipal Command of the Ghana Police Service, the Tendaana, the Chief Imam and the Yari-naa. In addition, members of the general populace of the territory of the Waala paramountcy were included in the sample. A sample size of 139 respondents was used for the research.

\subsection{Data Collection Methods}

Both primary and secondary data were used in this research. In total, fifteen (15) respondents were purposely selected and they took part in the semi-structured interview. To complement these individual interviews, four (4) focus group discussions were held in Wa. The eight (8) participants in each of the focus group discussion sessions were selected by their respective head of royal gate. The re- 
searcher had to depend on the heads of the royal gates because, matters of chieftaincy are very sensitive and a lot of people do not often want to discuss it. Four communities-Busa, Guli, Kperisi and Sing-were selected for inclusion because they are the legitimate divisional seats of the Wa paramountcy.

\section{Findings}

\subsection{Reasons for the Failure of the Modern Court System to Settle Chieftaincy Disputes}

As Table 1 demonstrates, around $25.89 \%$ of the respondents believe that the judges in formal court systems have little to no understanding of chieftaincy issues. This is why they often end up making conflicts worse, rather than solving them. Also, a proportion of $23.74 \%$ of respondents believe that the formal court system favours unscrupulous tactics. It can take a lot longer for cases to make it through the formal court system; an advantage to the accused. For $19.42 \%$ of respondents, issues of chieftaincy are deeply traditional in nature and, as such, should not be determined by contemporary mechanisms. Once again, this concern about time wasting is high on the agenda; many of the respondents were sure that unethical defendants would benefit from the longer, more complex court system. Around $17.26 \%$ of the respondents firmly believe that the contemporary courts are too slow and that this is a big part of its ineffectiveness. Finally, $13.66 \%$ of respondents claim that the ineffectiveness of the formal court system is more to do with issues of cost. It can be very costly to try and take a legal case in the formal court system. This means that lots of people simply do not get the opportunity to see their cases through to the end. These findings agree with [15] report that although court settlement is becoming more common for chieftaincy disputes, the community's rejection of court rulings is based on legal ignorance and that culturally-influenced conflict cannot be easily resolved with culturally insensitive methods. Consequently, [6] insists that chieftaincy disputes can be managed in part by the legal courts.

Table 1. Opinion of respondents regarding the reasons for the failure of the modern court system to settle chieftaincy disputes.

\begin{tabular}{lcc}
\hline \multicolumn{1}{c}{ Response } & Frequency & Percentage \\
\hline $\begin{array}{l}\text { The courts do not have much knowledge in traditional } \\
\text { matters }\end{array}$ & 36 & 25.89 \\
$\begin{array}{l}\text { Some people benefit from the perpetuation of chieftaincy } \\
\text { disputes before the law court }\end{array}$ & 33 & 23.74 \\
$\begin{array}{l}\text { Lack of willingness on the part of some people to provide } \\
\text { evidence in court }\end{array}$ & 27 & 19.42 \\
$\begin{array}{l}\text { The modern court system is time-consuming and tedious } \\
\text { It is very expensive to pursue a lawsuit in a modern court } \\
\text { system }\end{array}$ & 24 & 17.26 \\
& 19 & 13.66 \\
\hline
\end{tabular}

Source: Fieldwork, 2016. 


\subsection{Describe Indigenous Mechanisms for Solving Chieftaincy Conflicts among Waala-The Concept of Lesiri}

The term "lesiri" describes a diverse conceptual orientation of the Waala people of the Upper West Region, Ghana. It alludes to and references many great examples of social cohesion and control, as well as methods of conflict resolution carried out by the Waala. There are various ways in which the Waala convert these conceptual ideas into practical approaches in community life. The most valuable are via the application of an implicit, but powerful system for social control. The Waala are coaxed and sculpted into adhering to a clear social code. It is reinforced by ethical standards, the status quo, and a robust value and belief system. For instance, "for the Waala, the meaning of social cohesion must include the careful management of social ties, through the employment and continued emphasis on legends, fables, myths, beliefs, and ambitions. This application of the conventions of social cohesion is a constant mechanism and fundamental aspects of Waala life and culture, as they are keen to point out. It represents a culturally verified channel through which its members try to attain compatibility with the guidelines for suitable behaviour and maintain peace and harmony" (an interview with key informant, $2^{\text {nd }}$ May, 2016).

The Waala are taught to adhere to the guidelines for suitable behaviour, overcome conflicts peacefully, and make their decisions through the use of careful meditation and deliberation. According to a key informant, "refusal to follow the established parameters for social cohesion and cooperation is an attempt to destabilise the community. It is treated as a form of attack on the Waala community in its entirety" (an interview with a key informant, 1st May, 2016). This kind of behaviour is usually tackled with the use of financial penalties and vehement criticism from the community members. The people are tasked with demonstrating their obedience and respect for influential figures and helping to sustain these community guidelines. The importance of overcoming conflicts, while also adhering to the established rules of conflict resolution, is reinforced by the fact that the Waala people live in interconnected groups. These interconnected groups are acknowledged as one and the same group by the Waala. In fact, "the Waala people see themselves as one people hence "Te jaa bon yen" meaning, we are all the same" (an interview with key informant, $2^{\text {nd }}$ May, 2016). These groups must cooperate peacefully with one another because the smooth running of their lives depends on it. In other words, they cannot decide with whom they do and do not want to communicate; they must maintain positive ties with everybody. In the opinion of a key informant, "Waala people are all connected by blood, at some point or another, conflict resolution tends to be quite simple and almost always successful. The royal families originated from common descendants; "their foremost ancestor relocated to Wa from Manprugu" (an interview with a key informant, $2^{\text {nd }}$ May, 2016). Also, the nature of marriage, within the Waala community, prevents conflicts from arising. There is a keen desire to overcome challenges to chieftaincy in a peaceful manner because it is believed that all are 
connected through marriage as well. For the Waala, marriage is a social function that is bigger than the connection between the couple. According to a key informant, "marriage is not just for a woman and a man. It is an arrangement and a relationship between families. Therefore, a conflict between any two Waala people is a matter of blood. Ultimately for this community the aim is to keep problems small and insular (inside the community); and to find a solution before they need to be dealt with by a higher political authority" (an interview with a key informant, $10^{\text {th }}$ May, 2016).

For the Waala, each member of the community has a degree of responsibility to mitigate and overcome interpersonal problems. They understand perfectly that, if challenges and problems repeatedly reach the ears of the wider community, the likelihood is that they will involve the same obstinate and unreliable people. In the light of this, the ties between singular individuals and their respective family structures, as they pertain to conflict avoidance, reflect two important duties. Firstly, as a carrier of the family name, the individual has a duty to maintain a pleasing reputation for it by behaving appropriately. Secondly, family representatives have a duty to offer support to other family members if they become engaged in a conflict. The "head" of the family must also ensure that any accused members turn up for court meetings and that they settle any penalties that have been incurred as a result of criminal behaviour. Therefore, the socialisation functions within the Waala community are heavily influenced by the power and role of the family leaders. However, the wider community also has an important part to play, because those mutually held values, beliefs, and principles encourage members to follow the rules. In many ways, Lesiri is a network of shared and accepted understandings; either between the members of a single social group or between the members of distinctly different ones. It unites all within the established Waala social structure. For any Waala community, Lesiri is the enduring responsibility of the appointed leader. For all Waala communities, Lesiri is the enduring responsibility of the Wa-Naa (chief of Wa).

In his exploration of Lesiri, [5] explains that even the word itself has been shared. It is probably derived from Malinke, and the root of the term means "to unite" or "bring together as one". For the Malinke, the word "lesiri" describes an action that unites or brings individuals together with one another or their gods. In this community, there is a similar emphasis on social cohesion and bonding. Many stories are told about how individuals and their gods were united. So, it is very likely that the Waala term "Lesiri" is directly derived from the Malinke word "lasiri". Not only are the two words almost identical in sound and meaning, the educated Muslims of Wa are migrants from Mande, the original Malinke territory (Mali).

Specifically, Lesiri are only offered if there is a grave problem or conflict to solve. They are usually associated with the rights or responsibilities of the various Waala groups. For example, if one Waala group attempts to undermine the rights of a second, the wronged individuals are expected to refer to Lesiri about how they acquired these rights in the first place. The process is a way to rein- 
force their claim and make it clear to the combative group that not only do they have no standing on the issue, they also forget their promise to keep the peace and maintain social cohesion. As such, "Lesiri is more than just the telling of stories, because its primary purpose is to reinforce rights and claims. It represents the application of rights and responsibilities, both of which are formed by mutual agreements between individuals and intercommunity groups" (an interview with a key informant, $2^{\text {nd }}$ May, 2016).

The system and social mechanisms of Lesiris tate that all individuals, whether interacting with people from their social groups or others, are obliged to behave in a way that is suitable for their specific role and status within the community. To be precise, they must communicate with other members of the community in a way that is appropriate for their personal contribution to it. The Waala are expected to use kindness and compassion in their dealings with one another. If a person is involved in a conflict with another group member, they must do their best to prevent aggression or poor behaviour; it is best to avoid the combative individual or situation altogether. The problem should only be made the concern of the wider community if it is very serious and cannot be solved on a personal level.

For the individual, Lesiri is about adhering to the rules, conventions, values, and guidelines of the community. For the small groups within the community (and their respective leaders), it is about adhering to the rules laid out by the Wa-Naa (Chief of the Waala), particularly when it comes to intercommunity conflicts. Crucially, an inability to follow these rules leads to a reputation for recklessness and unreliability. In some severe cases, the dysfunctional individual is made a community outcast. Therefore, if a Waala member wishes to be seen as admirable and highly regarded, they must behave in a way that is compatible with Lesiri.

However, Lesiri has more than a singular significance and more than one meaning. It also refers to the responsibilities of influential figures and leaders; namely, that they have a duty to always remember the purpose and function of their role. Such considerations should define and dictate their responses to the group. They are obliged to safeguard the interests of all community members. They must be able to discuss, frame, evaluate, and fight for these interests, while also maintaining their reputation and status. According to Lesiri, "the duties that the Wa-Naa has towards the members of the Wa-Nabihi community can be split into two important obligations. First, as the Wa-Naa is the appointed leader of the Wa-Nabihi community, he has a duty to fight for the needs and interests of both individual members and the group as a whole. Second, the Wa-Naa is the appointed guardian of all Waala and is, therefore, held to a number of essential rules" (an interview with key informant, $10^{\text {th }}$ May, 2016). They are as follows:

- To safeguard and fight for the interests of Waala, both at individual and group levels. This should be the case even if these interests are in opposition to those of external forces;

- To mediate in all conflicts that develop between any of the groups of the 
community;

- And to function as a point of unity for all of the various Waala communities (particularly in cases of conflict and war).

Ultimately, "for the Waala people, the indigenous social system of Lesiri is a facilitator of personal and community interactions, particularly between leaders and the people who follow them. It essentially means that all chiefs-whether presiding over a small group or the entire community-have a duty to safeguard the interests of the people who, themselves, have willingly deferred to their wisdom" (an interview with key informant, $15^{\text {th }}$ May, 2016).

When interactions are based on Lesiri, it means that they are designed to maintain the status quo and keep social harmony and cohesion high. With the support of Lesiri, it becomes possible for a person or group to find justice for poor treatment. This solution is intended to be a positive one that does not involve violence or aggression. The aim is always to prevent conflict, barbarity, and damaging behaviours.

A key informant explains, "lesiri is an important tool for conflict resolution among Waala" (an interview with a key informant, $20^{\text {th }}$ May, 2016). So, it is fair to say that Lesiri is, for the Waala people, a valuable reflection of the principles and conventions of the community. The strength and value of Lesiri actively help members of the community to work well together. These actions do not only give maltreated individuals a chance to tell their story and receive a fair response, but they also make it easier to assign and appoint chiefs of various grades. They determine how and why a chief is appointed and provides guidance on how to overcome challenges to chieftaincy issues in a diplomatic and non-violent manner.

\subsubsection{Actors in Indigenous Approaches to Chieftaincy Conflict Resolution among the Waala}

For the Waala people, the indigenous methods used to resolve chieftaincy conflicts involve both community leaders and conventional systems of community justice and morality. With these tools, they approach and solve conflicts within and among the various Waala groups. They can almost always achieve this without the help of state organisations or outside support structures. The main actors in chieftaincy conflict resolution mechanism among the Waala include "the Tendaana of Wa, the Nabikpong of the entire royal family, the nabikpong of each of the four royal gates of the Wa paramount skin and elders of the Waala royal family" (an interview with key informant, $15^{\text {th }}$ May, 2016).

Within the Waala community, conflict is considered to be a danger to personal and social harmony. Conflict between individual members has the potential to undermine and damage established rules and principles; all of which are designed to safeguard and strengthen human interactions within and between groups in the Waala society. This principle further explains that personal conflicts are evil with the power to break down the community and threaten its future. Crucially, the Waala believe that conflict is to blame for external obstacles 
like drought, hunger, and death. In other words, if you persist in creating and maintaining conflict, the gods will deliver a worthy punishment. These beliefs mean that the Waala are extremely committed to upholding social harmony and keeping the community together. This is achieved through discussion, debate, compromise, intercession, and resolution [15]. There is much anthropological evidence to confirm that native methods of conflict resolution have long existed in communities across Africa.

According to an informant "The structure of Waala community exhibits a number of officials, hierarchical, and established approaches to conflict resolution. If an incident involves a number of disputants, from different groups, each will be represented by their respective leader. In some cases, the more senior leaders become directly involved with the resolution of the conflict, but their degree of contribution depends on the severity of the situation. For instance, more superficial conflicts are usually dealt with by the clan or the group leader. However, if incidents are more delicate, serious, or complex, they are handled by the court of the Wa Naa" (an interview with a key informant, $2^{\text {nd }}$ May, 2016).

Before Africa was occupied by colonial forces, the majority of indigenous communities already adhered to a carefully structured system of conduct and behaviour. The chiefs were the supreme leaders, but they relied on community elders to keep the peace. The "headman" was the figure in charge of the smallest community. This individual was expected to answer to the village chief. The village chief was expected to adhere to the word of the divisional chief. The divisional chief answered to the paramount chief, etc. These days, the chiefs still enter into a contractual promise with their communities. They promise to help promote peace and harmony for all members and work to enhance their everyday lives. It is interesting to note that, in each village, the social tools for conflict resolution, and the tackling of personal animosities are always present, robust, and reliable.

Historically, the indigenous court has always emphasised the importance of gathering valuable evidence, applying fair judgements, and supporting attempts at repair and recovery. With these steps, the chief (both individually and as part of an advisory group) can act as an agent for remediation and help disputants confront and solve their issues peacefully. During indigenous court sessions, the opposing individuals are not expected to talk directly to one another. They are strictly forbidden to disrupt proceedings and must not talk over the other party when they are given leave to speak. The submission of personal accounts, from each party, is followed by a mediated discussion phase. This is primarily defined by the cross-examination of witnesses. Once the accounts from the opposing individuals (or groups) have been thoroughly assessed, the chief and his elders are expected to make a decision on the outcome of the case. If the decision is made unanimously, it can be implemented immediately. It is interesting to note just how similar this indigenous court is to contemporary Western systems of justice; namely, trial by jury. In fact, the only major difference is the type of punishment 
that is delivered. This indigenous court is defined by notions of restoration; so both the "victim" and the wrongdoer are given a chance to contribute to discussions on what kind of punishment is fair and suitable. The primary purpose of this court is to deliver justice to the wronged party and make sure that the wrongdoer is adequately punished for his/her crime. However, there is also a great emphasis on unification; the victim and the offender are encouraged to come together and move past their differences. Since colonisation, more African leaders have tried to influence and change the indigenous courts in their respective countries. The problem is that most of these efforts have ended up diminishing the role of chiefs.

The indigenous pursuit of justice and social harmony is directed primarily by the most influential figures within the community; the chiefs, the royal families, the elders, the Tendaana, and others. According to a key informant, "these leaders are highly regarded, because they have a deep understanding of the rich values, beliefs, legends, and principles, which define the community" (an interview with a key informant, $20^{\text {th }}$ May, 2016). As they are heavily involved with the local factions and groups, they also have a unique understanding of the interactions between these different groups. These leaders are highly skilled when it comes to establishing and identifying effective methods of indigenous conflict resolution. With their abilities as speakers, advisors, and representatives to fall back on, they can reach peaceful and logical resolutions (Zartman, 2000). It must be noted that, even in spite of their influence and power within the community, none of the chiefs are given the right to forcefully implement punishments.

Instead, court punishments are all based on the social response. This is why things like community stigma, personal shame, and the fear of supernatural redress are so strong. For instance, the community believes that a person may be cursed or hexed if he/she does not abide by the rules or refuse to adhere to a court judgement. For this reason, there is never any need to turn to violence to make sure that court punishments are upheld. In fact, accused individuals have the freedom to ignore judgements that they do not agree with. The number of people that do that is very small indeed.

A punishment is only delivered if a group of representatives has agreed that it is just and suitable. All involved parties must be willing to tolerate or accept a proposed judgement and, once this has happened, the gods and the spirits of their ancestors are considered happy as well. In other words, indigenous justice is based wholly on consensus and agreement. This is why so much emphasis is placed on the contribution of all involved parties. It is a surprisingly modern form of remediation, but it is still shrouded in ceremony and ritual. The typical court case is preceded and proceeds by intense periods of prayer, and spiritual sacrifices. For communities like the Waala, these rituals are of great significance. They represent a form of conflict mitigation in their right. Ordinarily, the entire community is made a part of these rituals [15]. The people eat, sing, dance, and drink together. As already discussed, the opposing parties may not talk directly 
with one another during the court case. This rule is designed to prevent aggression and poor behaviour while tensions may be high. For the same reason, no party is allowed to disrupt the other while they are submitting their account. The submission of the accounts is followed by a period of comprehensive discussion and investigation. This may involve the cross-examination of witnesses, the presentation of circumstantial evidence, and the open airing of concerns. It may be necessary to ask for testimonies from friends and neighbours, reassess previous cases, or even ask the chief for a brief period of private deliberation.

\subsubsection{Fora for Handling Waala Chieftaincy Conflicts}

For the Waala royal families, the most valuable forum for handling chieftaincy disputes is Najagu. This canbe translated as "the court of the chief". The Najagu approach encourages opposing parties to look at the conflict from a broader perspective. The aim is to convince them that the dispute is superficial and of little importance, particularly within the grand scheme of things. This forum of conflict resolution is designed to bypass judicial discussions altogether and avoid the "victor" and "loser" attitude inherent within formal court-based judgements. The Najagu is a very adaptable system, but it is most commonly used by blood relatives who have valuable social and economic ties to protect. It is thought to be the most appropriate forum for chieftaincy conflict resolution among the Waala.

Within the Waala community, "the stakeholders of the Najagu system tend to be the elders of clans. They may also be other powerful people who are highly regarded for their knowledge, abilities, and personal characteristics. These elders are usually much respected and have a great standing within the community. They have the skill to convince and induce community members to obey their judgements and advice" (an interview with key informant, 10 ${ }^{\text {th }}$ May, 2016).

From a practical standpoint, the majority of conflicts are resolved at the family level. This is beneficial for all parties because most are keen to avoid long and drawn out cases at any cost. They are not only frustrating and time-consuming, but they can also be expensive. For the Waala, if a conflict can be resolved, there is a duty to try and do so in the easiest, quickest way possible. As the family is a big part of such proceedings-relatives have a responsibility to provide support and company during court cases-appeals to relatives are common; they are also expected to find an appropriate solution as quickly as possible.

Crucially, for the Waala people, "the Najagu structure represents a comprehensive picture of social values and conventions. The Najagu process can be roughly split into four key phases. The first (and the initial point of contact) is the court of the head of the royal gate known as the Dunuori-Ninkpong Jagu. It is the duty of this individual to resolve all conflicts associated with members of his community or gate. It represents the first step in the chain" (an interview with key informant, $10^{\text {th }}$ May, 2016).

Following this, "there is the court of the head of all the four royal gates. This is the Nabikpong (the head of the Waala royal family), and his job is to resolve 
conflicts among the four royal families or gates. It is important to point out that the Nabikpong has the power to reverse decisions already made by the Dunuori-Ninkpong, if they deem them to be unsuitable, unworkable, or unfair in any way" (an interview with key informant, 10 $0^{\text {th }}$ May, 2016).

According to an informant "In the unlikely event that a chieftaincy conflict cannot be resolved with the help of the Nabikpong, the case is passed up the chain to the Wa Naa and his elders. They are known as the Kpambiihi. It is the Kpambiihi who help the Naa to make a judgement and try to find a solution. The council of elders is usually made up of the leaders of each royal gate (there are four in total) and the Widaana, Foroko, and the Yari-Naa. Once a case gets raised to this level, the decision is almost always immovable and not up for debate. The chief has the final word, and his judgement must be adhered to. If the conflict involves the paramount Wa skin, it is the Tendaana of Wa who has the right to make a judgement; his decision is not up for discussion" (an interview with key informant, $10^{\text {th }}$ May, 2016). As explained by Louise [7], the Tendaana also has the final say if there is a chieftaincy conflict surrounding the selection of a new Wa Naa. This is not an infallible system because there are further disputes over the final decision in lots of cases. It is not unusual for some elders to find the judgement of a Wa Naa or a Tendaana to be unfair or unwise. This is precisely why the responsibility is handed over to just one person after a case has already been through many levels and layers of deliberation and discussion. At some point, there needs to be a ruling voice and the Tendaana is considered to be the most qualified in these situations (Figure 1).

The Najagu system requires each disputant to submit a clear and logical account. Once both accounts have been submitted, a team of elders quiz both parties about the details that they have given. The aim is to get to the root of the problem and identify the true cause, rather than trying to solve the minor issues that are only obscuring the real issue. This process involves the thorough application of evidence, cross-examinations, and witness statements. Interestingly, Najagu courts are made accessible to the public, and anybody can choose to ask the disputants questions. However, to retain control, all participants are expected to adhere to a rigorous set of rules. For instance, talking over a speaker is not permitted, and aggressive language is strictly forbidden as well. If these rules are continually flouted, the offending individual may be removed from the proceedings. As with western courts, contributors must take oaths before speaking. Accordingly "...before the commencement of any session to resolve a chieftaincy dispute, the disputants are made to take an oath" (an interview with a key informant, $2^{\text {nd }}$ May, 2016). The problem is that, once a dispute has reached this level of important attention, it can take a long time to reach a conclusion. The further up the chain of superiority a matter travels, the more complex the indigenous mechanisms of social justice become.

[16] points out that indigenous approach to resolving chieftaincy conflicts offer an alternative path to the court system or litigation method. This underscores the need to examine the impact of the Wa chieftaincy conflict on sustainability 


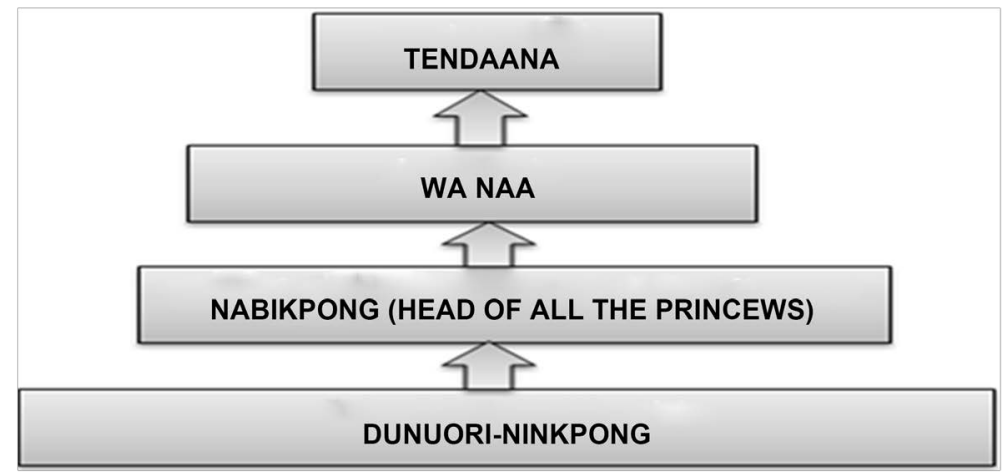

Figure 1. The chieftaincy dispute resolution process of the Waala. Source: Researcher's construct 2016.

of existing indigenous approaches to resolving the conflict. The opinion of respondents on whether the existence of the Wa chieftaincy conflict is an indication of the failure or ineffectiveness of indigenous approaches to chieftaincy conflict resolution are presented in Table 2.

As outlined in Table 2, around $56.11 \%$ of respondents claimed to believe that the existence of the Wa chieftaincy conflict is not a clear proof that the indigenous solutions are not effective. This agrees with [17] assertion that there is no consensus on the best approaches to conflict management and decision-making and above all, it is not possible to avoid conflict altogether. A further $10.07 \%$ did not have a firm opinion on this matter. On the other hand, $33.81 \%$ agreed with the statement. As espoused by [6], that conflicts occurring in the three Regions of Northern Ghana could be effectively managed if relevant points are taken from the effectiveness of existing indigenous methods and not disregarding them outrightly.

\subsubsection{Enforceability of Najagu Decisions on Chieftaincy Conflict Resolution}

Within the Waala community, "the leading political figures; the Tendaana, Foroko, Yari Naa, and the various chiefs and clan leaders also serve as the judicial administrators. Even though such a focused system of power and influence has led to corruption and tyranny in other areas of the world, it works very effectively for the Waala. In fact, it has encouraged a greater emphasis on honesty, reliability, honour, and sincerity across all spheres of the indigenous judicial system" (an interview with key informant, $15^{\text {th }}$ May, 2016). Here, discussion and careful thought have given political leaders the chance to improve their abilities, knowledge, and understanding of the people and their needs. For Wa, "this has been the best way to maintain peace, improve the status of the community, and keep its members happy. The variety of functions that the Waala royal families employ to try and implement their court judgements is, in many ways, shaped by the fragility of their political status and the fact that they do not have any power to enforce punishments" (an interview with key informant, $15^{\text {th }}$ May, 2016). 
Table 2. Opinion of respondents as to whether the existence of the Wa chieftaincy conflict is an indication of the failure of indigenous approaches to resolve chieftaincy conflicts.

\begin{tabular}{ccc}
\hline Response & Frequency & Percentage \\
\hline No & 78 & 56.11 \\
Yes & 47 & 33.81 \\
I don't know & 14 & 10.07 \\
Total & 139 & 99.99 \\
\hline
\end{tabular}

Source: Field data, 2016.

According to a key informant, "the main purpose of these indigenous approaches to conflict resolution is to gain a better insight into the interpersonal relationships between members of the Waala community. It is certainly true that no valid judicial judgement can be made without the full cooperation and contribution of both disputing parties. Once this cooperation has been given, the wheels of remediation and resolution can begin to turn; the decision makers are free to start considering suitable responses and solutions. The objective is always to bring the two disputing parties back to a state of non-conflict" (an interview with a key informant, $2^{\text {nd }}$ May, 2016).

It is through the fear of social shame and stigma that the Waala chiefs and elders can apply their influence, rather than through any active steps to enforce punishment. They can exploit community sentiments and attitudes as a way to convince obstinate disputants to tolerate and adhere to judgements. If an individual does refuse to accept a judgement and is shunned by the community, it is normal (and expected) for all members of that group to contribute to the response. It is common for shamed parties to be forced to wander the entire perimeter of the town while the villagers sing, shout, and play the drums. They may be further degraded with insulting songs and calls. If subjected to this punishment, the individual is also not permitted to communicate with anybody else; the community members must not interact with that person. They must not be visited or cared for when ill and, if the crime is severe enough, they may be refused burial in the public cemetery. The family members of the shunned persons are permitted to communicate with them, but there is no guarantee that this would not tarnish their reputation within the community. While the punishment may sound cruel and unusual, it is extremely rare. In fact, according to a number of trusted sources, nobody can recall having seen or heard about this penalty being applied. A possible explanation for this is the amount of social and community pressure to adhere to the judgement. It is considered to be extremely shameful to try and resist a judicial decision. Also, the relatives of the accused may choose to contribute to the settlement of financial penalties. If a fine is not settled, the individual is almost always shunned by the community, so the involvement of relatives can be the difference between a minor and a very severe punishment. 
If a dispute is solved, "the involved parties are asked to take a drink from a shared calabash. This is a symbol of unity and forgiveness; smoking a peace pipe. It represents the start of a new relationship. During this process, the community gods and the ancient spirits are called and asked to bear witness to the shared action. It is then their duty to swiftly punish the wrongdoer who decides to break this new partnership" (an interview with key informant $10^{\text {th }}$ May, 2016). This is reflective of another form of judicial enforcement. If an individual stubbornly disregards the judgement of the Najagu, the chief and his elders can turn to the supernatural for help. For instance, "curses and hexes are a common enforcement technique among the Waala and a popular choice of penalty for the royal decision makers. The threat of a curse can serve as a very powerful tool of persuasion and convince the accused to adhere to the given judgement" (an interview with key informant $10^{\text {th }}$ May, 2016). As already discussed, this is usually incentive enough for obstinate disputants; the chief does not need to resort to physical enforcement because the threat of supernatural punishments is intimidating enough

However, an interesting thing is happening in Waala communities. According to the contributors to the Focus Group meetings, it is becoming a lot harder to enforce the judgements of the Najagu deliberations, even with this threat of supernatural punishment. An informant explains, "shunning individuals is a technique that is not used anymore". It has no value as a method of enforcement. Now, many of the Waala royal families are Muslims who do not believe that the "gods use curses to keep followers in line" (an interview with a key informant, $10^{\text {th }}$ May, 2016). Unfortunately, this transition between the old and new systems of justice continues to be a challenge for the Waala. It has, "in many ways, been beleaguered by its failure to apply contemporary notions of equality, democracy, and good conduct. Such a development makes it clear that indigenous systems are not always compatible with contemporary societies and that modern judicial judgements now require legislation for support. It must be noted that in spite of the challenges faced by actors of indigenous conflict resolution approaches, the Wa Naa continues to tackle disputes associated with land, chieftaincy, civil matters, and criminal wrongdoings" (an interview with a key informant, $2^{\text {nd }} M a y$, 2016).

\subsection{Potential of Indigenous Conflict Resolution Mechanism in Solving the Wa Chieftaincy Conflict and Future Disputes}

The indigenous approaches to dispute resolution give remediation agents the chance to speak directly with the parties involved. This is very important because "the aim is to minimise the consequences, severity, and impact of such disputes, as far as possible. In both official and personal encounters, dispute resolution techniques encourage the oppositional forces to look at the situation from a new perspective. It is essential that they form new relationships from the old dispute, because the indigenous dispute resolutions are based on social cohesion and harmony. The people who most often arrange dispute resolution proc- 
esses also tend to be the mediators in a triangular configuration. These individuals are usually chiefs, elders, or other appointed leaders" (an interview with a key informant, $2^{\text {nd }}$ May, 2016). As communities grow, expand, and develop those traditional mechanisms for dispute resolution to become significantly more complicated.

For African communities, the approaches to indigenous dispute resolution are more than just a practical answer to a judicial problem; they are very much a part of healing and regeneration too. They encourage communities to consider all of the available options and to investigate the consequences of their decisions, both before and after they make them. An informant stated that "this is highly useful because a disregard for combating negative conduct can easily lead to violence, aggression, and bad judgements. On the other hand, dispute resolution supports the construction of a consensus, the maintenance of social ties, and the reinstatement of harmony and peace" (an interview with a key informant, $10^{\text {th }}$ May, 2016). For this to be possible, however, there needs to be an acknowledgement of the fact that disputes are rarely isolated issues. If they are not considered as being related to their environment and, specifically, their causes, the community will be destined to make the same mistake again. This is why the judicial system is so keen on evaluating the recent history of defendants; it aims to build up an accurate picture of how and why the dispute developed, not just what consequences it might have. By seriously considering disputes alongside their respective origins, it becomes easier to implement avoidance measures in the future.

The processes of dispute resolution, within indigenous communities, usually involve methods of cross-examination [18]. This is an effective way to assess evidence, verify facts, identify inconsistencies and gain a better understanding of the dispute.

Within indigenous communities, it is common for extra-judicial techniques to be used as a way to overcome disputes. According to a key informant, "swearing by the traditional skin of the land or by their ancestors is a means of deriving the facts on chieftaincy issues from disputants" (an interview with a key informant, $2^{\text {nd }}$ May. 2016). For instance, leaders can appeal to the gods and call on supernatural forces to mete out appropriate punishments. The gaze of the gods is also used as a way to gain additional insights into the situation. Needless to say, expressing a preference for either side, before the judgement, is highly frowned upon.

\subsection{Prospects of Indigenous Chieftaincy Conflict Resolution Mechanism among Waala}

Even in spite of massive upheavals, driven by the state, and a wealth of internal transformations, the core values and mechanisms of these approaches remain largely unchanged. The majority of conflicts that develop within the community are still solved by the community. The robust social interactions and relationships among the people serve to make the role of regeneration and appeasement 
utterly invaluable. As for the future of indigenous approaches to chieftaincy conflict resolution, things look positive; even if modern systems are ever encroaching.

The indigenously constructed responses to discussion, debate, remediation, compromise, and dispute settlement can continue to be successful actions as long as cultural values, chieftaincy knowledge, and local contributions are a good match. The relationships between them should serve to make community-based settlements more affordable, honest, and accommodate all community members. While the modern system has many distinct advantages, it cannot be said to have succeeded in tackling chieftaincy disputes. There is still a lack of acknowledgement and respect for indigenous methods within the formal court system. This can lead to negative consequences. For instance, people may not know where to turn for help. If the formal courts fail them, they may not have enough trust or faith in the indigenous systems, because they have never been properly endorsed. In some cases, this can encourage wronged people to try and take very direct and individual forms of action; for example, expressing violence towards a disputant or enemy. Unsurprisingly, this results in the destruction of social harmony and cohesion. One of the biggest benefits of the indigenous Waala system is that it is fast and easy. The majority of conflicts are resolved in a very short period. It is certainly not unusual for the judgement to be delivered within this timeframe. As well as being very fast, it is also highly affordable. According to a key informant, "an individual is only required to present a small quantity of cola to initiate proceedings in the courts of a chief" (an interview with a key informant, 20 ${ }^{\text {th }}$ May, 2016). The dispute is filed first and then, within 2 - 3 days, the court is arranged. This speed is important because the decision makers want to ensure that pertinent details about the conflict are remembered. The Waala system is, therefore, one of the most efficient approaches to solving disputes. On the other hand, it is important to note that some detractors believe this speed to be detrimental. By pushing the case through the courts so quickly, they argue that vital evidence is lost. In all of this, the primary aim is the restoration of social harmony, so a case may be considered successful if it has achieved this, no matter how brief the journey was.

There is another function that emphasises the significance and value of the indigenous system, particularly for the Waala communities. There is much focus on knowing the truth. Therefore, the indigenous process of conflict resolution is always keen on letting disputants take an oath before the commencement of any sitting; getting to the truth of the situation is a critical priority. In every version of the formal judicial setup, there has to be a loser and a victor. It could be argued that there are no real draws when it comes to the courts, even if decision makers would like the disputants to believe there is. In other words, the chief should not feel reluctant to deliver a certain decision because of the predicted response of the disputants. If the "losing" individual responds badly to the outcome and exhibits poor conduct, their presence may be demanded in court a second time as punishment for their actions. Most importantly, the indigenous system makes no place for violent redress. This is very rare within the Waala 
communities, for a number of reasons. The first is that punishment may then be brought against the aggressor for their attempts to exact personal justice. Also, a great deal of time and care is taken to help both parties comes to an acceptable compromise. It does not matter who is the victor and who is the loser because the top priority is restoring social harmony to the community and this cannot be achieved without the help of both parties. The only instances where punishments become much more severe for the loser is if they stubbornly refuse to adhere to the judgement laid out. The Waala system is surprisingly effective and sophisticated because it looks ahead to the future. It knows that, even if the accuser is made "the victor", so to speak, they cannot win if the social discord continues and begins to negatively impact their work or social obligations. For all of these reasons, the focus is always on bringing the two disputing parties together.

The reality is that some indigenous conflicts (particularly those pertaining to chieftaincy) are just not suitable to be pursued in the formal courts. Not only would the formalcourt system struggle to make sense of them, but they would also almost certainly fail to address these subtleties and social nuances. As already discussed, the concepts of "victor" and "loser" do not lie at the heart of the indigenous structures, as they do in the formal ones. This could explain why the formal courts have, thus far, been ineffective when it comes to matters of chieftaincy. It may also explain why the indigenous systems have not been completely killed off by the development of western judicial structures. In short, it seems best not to take responsibility for chieftaincy dispute resolution away from those who can handle it with skill and finesse.

Figure 2 presented below contain the views expressed by respondents, in relation to the prospects of indigenous approaches of chieftaincy conflict resolution among the Waala.

As Figure 2 demonstrates, around $43 \%$ of respondents believe that the prospects of the application of indigenous approach to chieftaincy conflict resolution are extremely positive. A further $30.93 \%$ expressed opinions that the prospects will likely be bright. This confirms [2] assertion that although ethnic diversity of members of the NHCs has a negative impact on its ability to resolve conflict effectively, conflict prone areas must not overlook the opportunity to achieve long-term peace and conflict management through the use of local community interventions. On the other hand, a proportion of $25.17 \%$ felt like the indigenous systems were not as effective as they once were. Despite some pessimistic views, the consensus is that indigenous approaches of chieftaincy conflict resolution will continue for the foreseeable future. However, it is clear that steps need to be taken to increase their feasibility, reliability, and longevity.

\subsection{What Can Be Done to Resolve the Wa Chieftaincy Conflict Successfully}

The respondents were also asked for their opinions on what steps could be taken to resolve the Wa chieftaincy conflict. Table 3 contains the responses of respondents. 


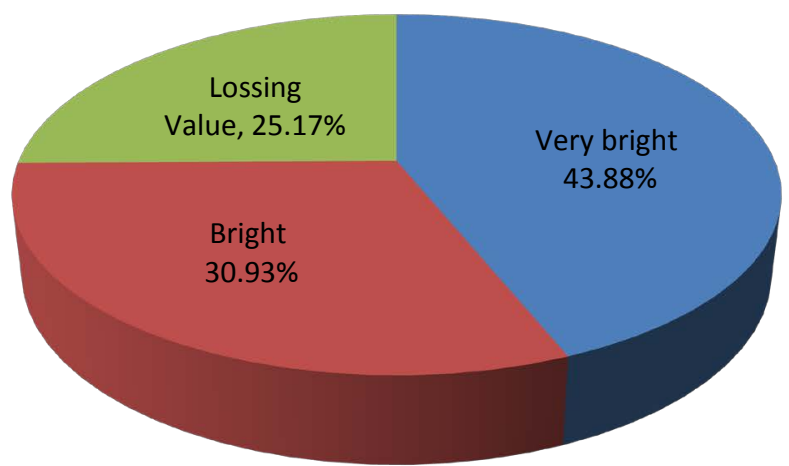

Figure 2. Views of respondents on the prospects of indigenous chieftaincy conflict resolution among the Waala. Source: Field data, 2016.

Table 3. What can be done to resolve the Wa chieftaincy conflict?

\begin{tabular}{lcc}
\hline \multicolumn{1}{c}{ Response } & Frequency & Percentage \\
\hline $\begin{array}{l}\text { The right traditional procedure of choosing chiefs must always } \\
\text { be adhered to }\end{array}$ & 45 & 32.37 \\
$\begin{array}{l}\text { Respect for the decisions of key traditional stake- } \\
\text { holders/opinion leaders }\end{array}$ & 39 & 28.05 \\
$\begin{array}{l}\text { Truth, sincerity and honesty must prevail among the royals and } \\
\text { opinion leaders }\end{array}$ & 32 & 23.02 \\
$\begin{array}{l}\text { Check bribery in the chieftaincy institution } \\
\quad \text { Total }\end{array}$ & 23 & 16.54 \\
& 139 & 99.98 \\
\hline
\end{tabular}

Source: Field data, 2016.

From the data in Table 3, about $32.37 \%$ of respondents indicated that to resolve the Wa chieftaincy conflict successfully, the right traditional procedure of choosing a Wa Naa must be followed while $28.05 \%$ of respondents revealed that the decisions of key traditional stakeholders should always be respected. Also, $23.02 \%$ of respondents mentioned that to get the Wa chieftaincy conflict resolved successfully, truth, honesty, and sincerity must prevail among the Waala royals and other opinion leaders. While $16.54 \%$ of respondents stated that bribery and other negative tendencies must be done away with to pave the way for the successful resolution of the Wa chieftaincy conflict. This confirms [19] findings that opportunistic individuals tend to use various means, including money, to secure their leadership even if they are not the rightful successors.

\subsection{Conclusions}

From the findings, the following conclusions were arrived at:

- The lesiri concept is an effective indigenous method of chieftaincy conflict resolution among the Waala of the Upper West Region of Ghana.

- The formal law courts are insensitive to the cultural norms of the Waala hence can not resolve the Waala chieftaincy conflict.

- Chiefs and other key stakeholders must cooperate to ensure that chieftaincy 
conflicts are resolved amicably.

- State officials and agencies should not interfere in the operations of the whale chieftaincy institution.

- The use of lesiri concept is capable of resolving the protracted Waala chieftaincy conflict.

\subsection{Recommendations}

It is recommended that the unique concept of Waala lesiri on traditional methods of chieftaincy conflict resolution be used to resolve modern day complex chieftaincy conflicts.

There should be an increased awareness of the use of non-violent strategies in responding to conflicts. Factions to the conflict need to display tolerance and understanding and make compromises and concessions.

An urgent need is apparent for the Wa Naa and the leadership of the four gates of the Waala skin to cooperate and communicate with one another, with the royal gates' members kept informed in relation to the cooperation taking place. A social contract that includes details of perceived infringements, punishments as well as the requisite policies and principles need to be drawn up with participation across the gates. Principal actors and interested parties, members and chiefs of the gates need to work for greater mutual esteem and integrity.

Furthermore, the skills and abilities of chiefs and other traditional stakeholders of the Waala kingdom should be enhanced through training to contribute in a productive manner to preserving peace and security in the traditional Waala setup. The abilities of chiefs of the Regional House of Chiefs and the Wa Traditional Council will be sharpened if they have the requisite skills. In fact, they can be given the authority and power, alongside members of the National House of Chiefs, to spearhead arbitration during disputes.

Municipal Assembly, Central Government, politicians as well as other interested bodies should allow the Waala chieftaincy institution to operate without interference so that it can contribute to the mitigation of conflict.

Given the fact that traditional societies have undergone some change, the potentials of indigenous approaches to conflict resolution are limited and are only appropriate in specific scenarios and societies. If the purpose and goal of achieving a peaceful society free of brutal conflict, traditional mechanisms of managing conflicts need to be mainstreamed.

\section{Conflicts of Interest}

The authors declare no conflicts of interest regarding the publication of this paper.

\section{References}

[1] Dougah, J.C. (1966) Wa and Its People. Institute of African Studies, Legon. 
[2] Wa Municipal Assembly (2011) Joint UN Human Security Programme, Community Plans.

[3] Tuokuu, F.X. (2011) Conflicts: The Bane of Development in Northern. www.Ghanaweb.Com

[4] Tuurey, G. (1982) An Introduction to the Mole-Speaking Community. Ghana Education Service, Wa.

[5] Wilks, I. (1989) Wa and the Wala-Islam and Polity in Northern Ghana. Cambridge University Press, Cambridge.

[6] Awedoba, A.K. (2009) An Ethnographic Study of Northern Ghana Conflicts: Towards a Sustainable Peace. Sub-Sahara Publishers, Accra.

[7] Daanaa, H.S. (1992) The Impact of State Law on Custom and Leadership in a Post-Colonial State: A Legal Historical Case Study of Centralized Wa and Acephalous Chakali in Northern Ghana. Unpublished Ph.D Thesis, London.

[8] Bin Salih, M. (2008) The Kingdom of Wa: Elucidation of Our Origins and Settlement. Salihsons, Accra.

[9] Ayim, M. (1991) Dominance and Affiliation: Paradigms in Conflict. Informal Logic, 13.

[10] Fuseini, A. (2009) The Impact of Chieftaincy Disputes on Human Development. The Case of the Wa Chieftaincy Dispute.

[11] Ghanaian Times (2007) New Wa Naa's Nomination Opposed. 22.

[12] Daily Graphic (2012) One Shot Dead in Wa Chieftaincy Clash. 20.

[13] Duogu, Y. (2011) Guest Speaker Address by Hon. Municipal Chief Executive on the Occasion of the $48^{\text {th }}$ Annual Regional Conference of Ahmadi Muslims of the Upper West Region, Wa.

[14] Yakubu, M.A. (2010) Increasing Violent Conflicts in the North: The Youth Must Rethink. www.myjoyonline.com

[15] Fred-Mensah, B. (2005) Nugormesese: An Indigenous Basis of Social Capital in a West African Community. $1 \mathrm{~K}$ Notes, No. 86, World Bank. http://www.worldbank.org/afr/ik/default.htm

[16] Osi, C. (2008) Understanding Indigenous Dispute Resolution Process and Western Alternative Dispute Resolution. Cardozo Journal of Conflict Resolution, 10, 183.

[17] Rahim, M.A. (2002) Toward a Theory of Managing Organizational Conflict. The International Journal of Conflict Management, 13, 206-235.

[18] Olaoba, O.B. (2000) The Significance of Cross-Examination in Yoruba Traditional Jurisprudence. John Archers.

[19] Boafo-Arthur, K. (Ed.) (2006) Voting for Democracy in Ghana, the 2004 Elections in Perspective, Vols. I \& II. Department of Political Science, Freedom Publication, Accra. 